\title{
UK Citizens as Former EU Citizens: Predicament and Remedies
}

\author{
Reuven (Ruvi) Ziegler
}

This contribution, like those immediately preceding it, is written in the aftermath of the 23rd June 2016 referendum on the UK continued membership of the EU. At the time of writing, there are precious few known knowns ('Brexit means Brexit'), critical known unknowns (notably, the nature of future relations between the UK and the EU-27 and ensuing free movement arrangements), and doubtlessly many unknown unknowns. Nevertheless, the premise for this contribution will be that, following negotiations (pursuant to Article 50 of the Treaty on European Union) ${ }^{1}$ the UK will cease to be a member of the EU, and the EU treaties will cease to apply to it on exit day (E-day).

Before turning to the legal predicament of UK citizens, and its potential remedies, it would be helpful to consider the effect on the estimated 3.1 million citizens of the EU-27, resident in the UK (unofficial data: Migration Observatory) ${ }^{2}$.

\section{EU-27 citizens resident in the UK}

The status of citizens of other EU Member States qua EU citizens will not be affected by the UK's departure. Their ability to continue to exercise their acquired rights in post-Brexit UK would largely depends on decisions which can be made by the UK Parliament irrespective of the outcome of negotiations with the EU-27.

Hence, the UK could 'take back control' over (future) immigration and nevertheless maintain, mutatis mutandis, the arrangements in the Immigration

\footnotetext{
1 The Lisbon Treaty, available at http://www.lisbon-treaty.org/wcm/the-lisbontreaty/treaty-on-European-union-and-comments/title-6-final-provisions/137article-50.html.

2 The Migration Observatory at the University of Oxford (2016), Commentary: Here today, gone tomorrow? The status of EU citizens already living in the $U K$, available at http://www.migrationobservatory.ox.ac.uk/resources/commentaries/today-gone-tomorrow-status-eu-citizens-already-living-uk/.
} 
(European Economic Area) Regulations $2006^{3}$ which implement the Citizens Directive. ${ }^{4}$ Nevertheless, while the UK government (July 2016 statement) ${ }^{5}$ 'fully expects' that the legal status of EU-27 citizens 'will be properly protected', it refuses to give assurances before the commencement of the withdrawal negotiations. At the time of writing, parliamentary initiatives (Early Day motion $259^{6}$, EU Citizens Resident in the UK (Right to Stay) Bill ${ }^{7}$, and a Rights of EU Nationals motion ${ }^{8}$ ) as well as public campaigning (see here ${ }^{9}$ ) have not yet come to fruition (but one remains hopeful).

Similarly, there is nothing preventing the UK from continuing to enfranchise EU-27 citizens in local government elections (pursuant to section 2 of the Representation of the People Act $1983^{10}$ ) even when it is no longer bound to do so in order to implement its treaty obligations. Notably, the UK has broadly interpreted the phrase 'municipal elections' in Article 20(2)(b) of the Treaty on the Functioning of the European Union ${ }^{11}$ so that EU-27 citizens can currently vote in elections for devolved administrations (Scottish Parliament, Welsh Assembly, Northern Ireland Assembly), for the London Assembly, and for mayors (where they are directly elected). Most notably, EU-27 citizens, resident in Scotland, were enfranchised in the 2014 Scottish independence referendum (see EUDO forum discussion ${ }^{12}$ ).

3 http://www.legislation.gov.uk/uksi/2006/1003/contents/made.

4 http://eur-lex.europa.eu/LexUriServ/LexUriServ.do?uri=OJ:L:2004:229:0035: 0048:en:PDF.

5 https://www.gov.uk/government/news/ statement-the-status-of-eu-nationals-in-the-uk

6 http://www.parliament.uk/edm/2016-17/259.

7 http://services.parliament.uk/bills/2016-17/eucitizensresidentintheunitedkingdomrighttostay.html.

8 https://hansard.parliament.uk/commons/2016-10-19/debates/F1337420-EBD9413C-949B-A4AEA0832B2C/RightsOfEUNationals.

9 'Government can "unilaterally" grant EU citizens right to remain after Brexit', The Guardian, 18 October 2016, available at https://www.theguardian.com/ politics/2016/oct/18/

government-unilateral-eu-citizens-right-to-remain-brexit-roger-casale-nicolashatton.

10 http://www.legislation.gov.uk/ukpga/1983/2/section/2.

11 https://europadatenbank.iaaeu.de/user/view_legalact.php?id=24

12 Ziegler, R., J. Shaw \& R. Bauböck (eds.) (2014), 'Independence Referendums: Who Should Vote and Who Should be Offered Citizenship', Robert Schuman Centre for Advanced Studies, EUDO Citizenship Observatory Working Paper 2014/90, available at ?http://cadmus.eui.eu/bitstream/handle/1814/32516/ RSCAS_2014_90.pdf. 
In contradistinction, their right to 'participate in the democratic life of the Union' (Article 10(3) of the Treaty on European Union ${ }^{13}$ ) is inevitably going to be affected, as the UK will no longer send MEPs to the European Parliament whom they could elect. Nevertheless, citizens of the EU-27 need not thereby fully lose their right to vote for MEPs. A 2015 European Parliament report ${ }^{14}$ notes that 22 Member States of the EU-27 allow their citizens to vote for the European Parliament when they reside in a non-EU state. There are sound reasons for the EU institutions to pressure the remaining five to change their policy, especially in light of the Court of Justice's Zambrano ${ }^{15}$ ratio that Member States should not hinder [43] 'the genuine enjoyment of the substance of rights conferred by virtue of their status as citizens of the Union'. Moreover, it is not implausible that the Court of Justice's Delvigne ${ }^{16}$ ratio (concerning disenfranchisement of prisoners, discussed here ${ }^{17}$ ) will prompt a legal challenge to disenfranchisement of Union citizens residing in non-EU Member States. In addition to the legal framework, it is submitted that the policy reasons for enfranchisement apply $a$ fortiori when Member State citizens reside in a former EU Member State.

\section{UK citizens as former $\mathbf{E U}$ citizens}

Under the current treaty arrangements, all UK citizens who do not hold the citizenship of another EU Member State will cease to be citizens of the Union, whether or not they have exercised their EU mobility rights: citizenship of an EU Member State is a necessary and sufficient condition for Union citizenship (Article 9 TEU) ${ }^{18}$.

13 http://eur-lex.europa.eu/legal-content/en/

TXT/?uri=CELEX\%3A12012M\%2FTXT

14 Poptcheva, E. M. (2015), Disenfranchisement of EU Citizens resident abroad. Situation in national and European elections in EU Member States, available at http://www.europarl.europa.eu/RegData/etudes/IDAN/2015/564379/ EPRS_IDA(2015)564379_EN.pdf

15 Judgment of the Court (Grand Chamber) of 8 March 2011, available at http:// eur-lex.europa.eu/legal-content/EN/TXT/?uri=CELEX\%3A62009CJ0034.

16 ECLI:EU:C:2015:648, available at http://curia.europa.eu/juris/document/ document.jsf?text $=\&$ docid $=169189 \&$ pageIndex $=0 \&$ doclang $=\mathrm{EN} \&$ mode $=$ req $\&$ $\operatorname{dir}=\&$ occ $=$ first\&part $=1 \& \operatorname{cid}=115706$.

17 Ziegler, R. (2016), 'The "Brexit" Referendum: We Need to Talk about the (General Election) Franchise', Verfassungsblog On Matters Constitutional, available at https://verfassungsblog.de/

the-brexit-referendum-we-need-to-talk-about-the-general-election-franchise/.

$18 \mathrm{http} / /$ eur-lex.europa.eu/legal-content/en/TXT/?uri=CELEX\%3A12012M\%2F TXT. 
Bauböck lucidly describes a 'cleavage' between mobile and immobile EU citizens, characterising the Brexit vote as 'a political revolt of immobile against mobile Europeans'. But, as Oberman notes, 'the right to immigrate' means that today's immobile EU citizens can choose whether to become mobile in future: indeed, while for citizens of other EU Member States, the choice may come early in life (see Paskalev's and Sardelić's contributions) many Britons (cue Harry Shindler ${ }^{19}$, excluded from voting in the EU referendum pursuant to the 15 year of non-residence $\operatorname{bar}^{20}$ ) made use of mobility rights in their later years. To borrow Joni Mitchell's exhortation, for many Britons, the vote to leave may yet turn into a case-in-point of 'you don't know what you've got till it's gone'.

The Court of Justice held in Rottmann ${ }^{21}$ that, when a Member State strips its citizen of her or his citizenship, the situation [42] 'falls by reason of its nature and its consequences, within the ambit of EU law'. Consequently [55-56] 'each individual decision...must be in line with the European principle of proportionality' and 'take into consideration...the loss of the rights enjoyed by every citizen of the Union'. Hence, it is perhaps ironic that the prospective en masse stripping of EU citizenship from UK citizens (save for those who are also citizens of another EU Member State) will likely occur without (Court of Justice) judicial scrutiny as and when the treaties cease to apply to the UK. It casts a realistic light on the judgment in $\mathrm{Chen}^{22}$ where the Court of Justice pronounced that [25] 'Union citizenship is destined to be the fundamental status of nationals of the Member States.'

Nevertheless, as Advocate General Maduro noted in his opinion in Rottmann ${ }^{23}$ [23] 'Union citizenship assumes nationality of a Member State but it is also a legal and political concept independent of that of nationality. Nationality of a Member State not only provides access to enjoyment of the rights conferred by Community law; it also makes us citizens of the Union.

19 https://www.youtube.com/watch?v=I3BNvWFA9ME.

20 Ziegler, R. (2016), 'The referendum of the UK's EU membership: No legal salve for its disenfranchised non-resident citizens', Verfassungsblog On Matters Constitutional, available at http://verfassungsblog.de/ the-referendum-of-the-uks-eu-membership-no-legal-salve-for-its-disenfranchised-non-resident-citizens/.

$21 \mathrm{http}: / /$ curia.europa.eu/juris/celex.jsf?celex=62008CJ0135\&lang $1=$ en\&type $=\mathrm{T}$ XT\&ancre $=$

$22 \mathrm{http}$ //curia.europa.eu/juris/showPdf.jsf?text $=\&$ docid $=49231 \&$ pageIndex $=0 \& \mathrm{~d}$ oclang $=$ en $\&$ mode $=1$ st $\&$ dir $=\&$ occ $=$ first $\&$ part $=1 \& \operatorname{cid}=60233$

$23 \mathrm{http}$ //curia.europa.eu/juris/document/document.jsf?text=\&docid=72572\&page Index $=0 \&$ doclang $=$ en $\&$ mode $=1$ st $\&$ dir $=\&$ occ $=$ first $\&$ part $=1 \& \operatorname{cid}=1131383$ 
European citizenship is more than a body of rights which, in themselves, could be granted even to those who do not possess it.' Coupled with the Zambrano ratio (above), the question is: how can the predicament arising from UK citizens' loss of EU citizenship status and rights be addressed?

\section{Automatic/accelerated naturalisation of UK citizens (residing) in other member states}

Politicians in Germany ${ }^{24}$ and Italy ${ }^{25}$ were reported to have suggested naturalisation of 'young' Britons residing in their respective states, and many Britons have (individually) started searching for a nationality link, most notably to Ireland ${ }^{26}$. Now, it is within the gift of Member States to determine their naturalisation criteria, and requires no treaty change; the UK tolerates acquisition of other nationalities.

However, notwithstanding their well-intentioned premises, such proposals pose substantive challenges: First, they will inevitably lead to divergent treatment of UK citizens across the Union, as some states will not relax their naturalisation requirements to accommodate UK citizens. Second, relaxation of naturalisation requirements (which may include citizenship tests) on an ad hoc basis for one national group may be deemed unjustified. In this context, it is noteworthy that the Union generally encourages states that do not permit dual nationality to relax their objections in relation to the acquisition of the nationality of another Member State (Germany, for instance, generally requires its nationals to obtain permission before acquiring another nationality, save in the case of another EU Member State or Switzerland). In contradistinction, the Maltese 'citizenship for sale' (see EUDO debate ${ }^{27}$ ) caused a degree of discomfort; hence, doubts could be raised as to the

24 'German politicians propose offering young Britons dual citizenship', The

Guardian, 3 July 2016, available at https://www.theguardian.com/world/2016/

jul/03/german-politicians-propose-offering-young-britons-dual-citizenship.

25 'Italy's Renzi suggests "ad hoc" citizenship for young Britons abroad', $E B L$ News, 29 June 2016, available at https://eblnews.com//news/europe/ italys-renzi-suggests-ad-hoc-citizenship-young-britons-abroad-27245.

26 'Huge rise in Britons applying for Irish citizenship after Brexit vote', The Guardian, 13 October 2016, https://www.theguardian.com/world/2016/oct/13/ huge-rise-in-britons-applying-for-irish-citizenship-after-brexit-vote

27 Shachar, A. \& R. Bauböck (eds.) (2014), 'Should Citizenship be for Sale?', Robert Schuman Centre for Advanced Studies EUDO Citizenship Observatory Working Paper 2014/01, Florence: European University Institute, available at http://cadmus.eui.eu/bitstream/handle/1814/29318/RSCAS_2014_01. pdf? sequence $=1$. 
propriety of e.g. en masse waver of residence requirements for naturalisation. Third, naturalisation is an inexact remedy: Britons have an effective nationality, albeit one whose instrumental value for free movement will have (potentially, depending on the UK-EU future relations) been adversely affected.

\section{(Partial) decoupling of Union citizenship from Member State citizenship}

Morgan's proposition to create 'a form of Union citizenship unmediated by any prior national citizenship' appears to offer a more direct link between the predicament (loss of EU citizenship rights) and the remedy. However, by making the offer 'conditional on Britain offering current EU citizens full national citizenship in Britain' or 'contingent on certain forms of equitable treatment for current EU citizens resident in Britain', and by making the reattainment (viz. retention) of EU citizenship financially contingent $(€ 10,000)$ so as to 'discourage countries from thinking that they can secede from Europe while enjoying the full benefits of membership', he significantly weakens the normative basis of his proposition. If the Union ought to be concerned about the individual loss of EU citizenship status and rights, why should its retention be made contingent on policy choices of a former Member States? This seems like the UK government's 'bargaining chips' or 'cards' strategy ${ }^{28}$ in reverse (it is also noteworthy, for the reasons noted above, that the predicament of EU-27 citizens residing in the UK does not arise from an ineffective nationality).

Moreover, it is not only morally contestable, but also puzzling how making the re-attainment of Union citizenship costly for individuals will discourage states from 'seceding' (withdrawing) from the Union: it seems plausible to assume that (most if not all of) those UK citizens who would wish to retain their Union citizenship had preferred that the UK remain in the Union, but were outvoted. If the Union is concerned about preservation of their individual status and rights, it is due to the disjuncture between their own preferences and the aggregate preferences of their polity. Finally, it is rather unclear whether Morgan proposes to open the Union citizenship route to all UK citizens who do not hold the citizenship of another EU Member State, or just to those who have already exercised mobility rights.

\footnotetext{
28 'Liam Fox: EU nationals in UK one of “main cards" in Brexit negotiations', The Guardian, 4 October 2016, available at https://www.theguardian.com/ politics/2016/oct/04/

liam-fox-refuses-to-guarantee-right-of-eu-citizens-to-remain-in-uk.
} 
Dawson and Augenstein argued elsewhere ${ }^{29}$ that the decision to withdraw Union citizenship (viz. obtaining Union citizenship through citizenship of a Member State) should rest not with the withdrawing state but with the individual EU citizen, who may either retain or renounce his or her citizenship. This proposition appears more comprehensive and normatively consistent: it would apply to all Britons (whether or not they have exercised mobility rights), recognising their unique predicament as citizens of a former Member State, and thus distinguishing them from citizens of other states, for whom the route to Union citizenship will remain via acquisition of Member State citizenship. It also does not tie their fate to that of the EU-27 citizens. Indeed, there is arguably a qualitative difference (for individuals) between exclusion from club membership and benefits, on the one hand, and non-inclusion therein, on the other hand: many organisations (think universities) retain a special relationship with their alumni.

However, the decoupling of Union citizenship from citizenship of a Member State would require a fundamental treaty change. What will the creation of two categories of Union citizens do to the self-perception of the EU as an '[ever closer] union among the peoples of Europe' (Article 1 TEU $^{30}$ ), a 'demoicracy' a-la Nicolaïdis ${ }^{31}$ ? To draw on the university alumni analogy, their privileged status (compared with members of the public) is manifested by retention of access to entitlements generally restricted to members - but they are nonetheless former members.

\section{UK citizens as Third Country Nationals}

Absent treaty change that will address the predicament of UK citizens qua former Union citizens, UK citizens who do not hold the citizenship of another Member State on E-day will become Third Country Nationals (TCN). Mobile UK citizens may qualify as Long Term Residents (LTR). As

29 Dawson, M. \& D. Augenstein (2016), 'After Brexit: Time for a further Decoupling of European and National Citizenship?', Verfassungsblog On Matters Constitutional, available at http://verfassungsblog.de/ brexit-decoupling-european-national-citizenship/.

30 Consolidated Version of the Treaty of the European Union, available at http:// eur-lex.europa.eu/LexUriServ/LexUriServ.do?uri=OJ:C:2008:115:0013:0045:e n:PDF.

31 Nicolaïdis, K. (2012), 'The Idea of European Demoicracy,' in J. Dickson \& P. Eleftheriadis (eds.), Philosophical Foundations of European Union Law, 247-274. Oxford: Oxford University Press, available online http://kalypsonicolaidis.com/wp-content/uploads/2015/02/2013_TheIdeaofDemoicracy.pdf. 
such, they will benefit from the LTR Directive ${ }^{32}$ (as amended ${ }^{33}$ in 2011 to extend its scope to beneficiaries of international protection) and from the Right to Family Unification Directive ${ }^{34}$. Both Directives apply in all EU-27 Member States except Ireland (where UK citizens have a free-standing right to reside that preceded Union membership) and Denmark.

Pertinently for this debate, after five years of continuous residence (Article 4 LTRD) and subject to satisfying additional criteria, LTRs acquire the right to reside in the territory of Member States other than the one which granted them the long-term residence status (Article 14(1) LTRD); following the acquisition of LTR status, they enjoy substantive entitlements under EU law wherever the reside in the Union, including equality of treatment with Union citizens in a wide range of economic and social matters (Article 11 LTRD) and enhanced protection against expulsion (Article 12 LTRD). A fairly modest legislative change to the LTRD that would mitigate the predicament of UK citizens could be the granting of LTR status to mobile UK citizens, irrespective of whether they have met the continuous residence and/or other LTRD requirements.

One of the substantive differences between mobile EU citizens and TCNs concerns political participation. TCNs are not entitled to participate in the 'democratic life of the Union'; nor are Member States required to enfranchise them in local elections. However, nothing prevents Member States from so doing: indeed, the (limited ${ }^{35}$ ) number of signatories to the Council of Europe Convention on the Participation of Foreigners in Public Life at Local Level ${ }^{36}$ are committed to residence-based enfranchisement on the local level and among the EU-27, eleven states permit TCNs to vote in local

32 Council Directive 2003/109/EC of 25 November 2003 concerning the status of third-country nationals who are long-term residents, available at http://eur-lex. europa.eu/legal-content/en/ALL/?uri=CELEX:32003L0109.

33 http://eur-lex.europa.eu/LexUriServ/LexUriServ.do?uri=OJ:L:2011:132:0001:0 004:EN:PDF

34 Council Directive 2003/86/EC of 22 September 2003 on the right to family reunification, available at http://eur-lex.europa.eu/LexUriServ/LexUriServ.do? uri=OJ:L:2003:251:0012:0018:en:PDF.

35 Chart of signatures and ratifications of Treaty 144, available at https://www. coe.int/en/web/conventions/full-list/-/conventions/treaty/144/signatures? p_auth $=0 \mathrm{ZKv} 2 \mathrm{OhD}$.

36 Convention on the Participation of Foreigners in Public Life at Local Level, available at https://www.coe.int/en/web/conventions/full-list/-/conventions/ rms/090000168007bd26. 
elections. The Union could amend the LTR by disaggregating certain citizenship rights, such as national treatment in respect of local voting rights, from Union citizenship.

\section{Ruptures in the legal terrain}

The Brexit vote came about, in part, due to anxieties surrounding the (perceived) absence of suitable controls on the exercise of the right to free movement by Union citizens. To borrow an earthquake metaphor, the extent to which the aftershocks of $23^{\text {rd }}$ June 2016 will rupture the Union's legal terrain remains to be seen.

Open Access This chapter is licensed under the terms of the Creative Commons Attribution 4.0 International License (http://creativecommons.org/licenses/by/4.0/), which permits use, sharing, adaptation, distribution and reproduction in any medium or format, as long as you give appropriate credit to the original author(s) and the source, provide a link to the Creative Commons license and indicate if changes were made.

The images or other third party material in this chapter are included in the chapter's Creative Commons license, unless indicated otherwise in a credit line to the material. If material is not included in the chapter's Creative Commons license and your intended use is not permitted by statutory regulation or exceeds the permitted use, you will need to obtain permission directly from the copyright holder.

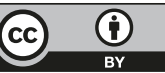

